\title{
Manajemen sumber daya manusia dalam perusahaan berdasarkan nilai Pancasila
}

\author{
Alif Lukmanul Hakim, ${ }^{a, 1}$ Syahrul Kirom ${ }^{\text {b,2* }}$ \\ ${ }^{a}$ Universitas Islam Indonesia, Yogyakarta \\ ${ }^{\mathrm{b}}$ IAIN Syekh Nurjati, Cirebon \\ ${ }^{1}$ alif.lukmanulhakim@uii.ac.id, ${ }^{2}$ Syahrulkirom1984@syekhnurjati.ac.id \\ * korespondensi penulis
}

\begin{abstract}
ABSTRAK
Manajemen sumber daya manusia adalah perencanaan, pengorganisasian, pelaksanaan dan pengontrolan terhadap sumber daya manusia dalam organisasi untuk mencapai tujuan secara efektif dan efisien. Sumber daya manusia sebagai salah satu sumber daya yang ada dalam organisasi memegang peranan penting dalam keberhasilan pencapaian tujuan organisasi. Berhasil atau tidaknya tergantung pada kemampuan sumber daya manusia dalam menjalankan tugas dan fungsinya. Apalagi jika penerapannya berlandaskan pada nilai-nilai Pancasila yang mengedepankan nilai ketuhanan dan kemanusiaan.
\end{abstract}

Kata kunci: manajemen, sumber daya manusia, nilai pancasila

\begin{abstract}
The definition of human resource management rules out a great understanding of planning, organizing, implementing anda controlling all of the sources within the company in order to reach the goal both effectively. Human resource significantly plays an important key to achieve the set up the goals of the organization as a whole. Moreover it also indicated the factor of organization's achievement overall. Since it is an urgent thing to manage then this research finds out the possibility to implement the values of Pancasila focusing more on the first and second verse stating the belief of the only God and humanity as well.
\end{abstract}

Keywords: management, human resource, values of pancasila

Copyright (C2020 Universitas Ahmad Dahlan, All Right Reserved

\section{PENDAHULUAN}

Sumber Daya Manusia adalah kumpulan orang yang siap, bersedia dan mampu berkontribusi terhadap usaha bersama untuk mencapai tujuan organisasi. Dalam ilmu kependudukan, konsep sumber daya manusia ini dapat dianggap setara dengan konsep tenaga kerja yang meliputi angkatan kerja dan bukan angkatan kerja. Angkatan yang kerja sering kita sebut juga dengan pekerja.

Organisasi pada dasarnya merupakan kerja bersama antara dua orang atau lebih dalam rangka mencapai suatu tujuan bersama. Organisasi adalah kumpulan atau tempat berkumpulnya orang, proses pembagian kerja (job description) antara orang-orang tersebut dan adanya sistem kerja sama atau sistem koneksi sosial diantara orang-orang tersebut dalam kurun waktu tertentu.

Agar tujuan tercapai, organisasi memerlukan berbagai macam sumber daya. Mulai dari sumber daya manusia, peralatan, mesin, keuangan, dan sumber daya informasi. Setiap sumber daya memiliki peran, posisi, dan fungsinya masing- masing. Sebagai suatu sistem sumber daya-sumber daya tersebut akan berinteraksi dan saling bekerja sama sehingga tujuan dapat tercapai denga efektif dan efisien serta berkelanjutan (sustainable).

Dengan berpijak pada pendekatan sistem, manajemen sumber daya manusia merupakan bagian dari sebuah sistem yang lebih besar yaitu organisasi. Oleh karena itu upaya-upaya sumber daya manusia hendak dievaluasi berdasarkan kontribusinya, berdasarkan produktivitas organisasi. Dalam praktiknya model manajemen sumber daya manusia merupakan sebuah sistem terbuka yang terbentuk dari bagian-bagian yang saling berhubungan antara bagian yang satu dengan yang lainnya. Setiap organisasi, misal perusahaan, sosial, pemerintahan mempunyai tujuan yang dapat dicapai melalui pelaksanaan pekerjaan tertentu, dengan mendayagunakan dan mengoptimalkan sumber daya yang ada dalam organisasi. Dan yang paling penting dalam mencapai organisasi adalah adanya sumber daya manusia yang kompeten, berkualitas dan berintegritas. 


\section{METODE}

Penelitian ini sepenuhnya bersifat kepustakaan (Library Research). Objek formal penelitian ini adalah pada sila-sila dalam Pancasila. Sedangkan, untuk objek material adalah manajemen Sumber daya Manusia dalam Perusahaan. Sila pertama dan kedua ini digunakan sebagai pisau analisis dalam membedah dan melakukan sebuah pembacaan, dan analisis secara kritis-filosofis terhadap manajemen sumber daya manusia dalam sebuah perusahaan. Dalam penelitian ini dengan menggunakan metode sebagai berikut diantaranya metode deskriptif, yakni proses ini digunakan untuk mengambarkan dan menjelaskan manajemen sumber daya manusia dalam perusahaan, sedangkan, metode Interpretasi, yakni proses analisis ini dilakukan dengan melakukan interpretasi, terhadap manajemen sumber daya manusia dalam sebuah perusahaan yang dikaitkan dengan sila pertama dan sila kedua, apakah sudah terimplementasikan sila pertama dan kedua dalam manajemen sumber daya manusia di sebuah perusahaan.

\section{HASIL DAN PEMBAHASAN}

Kehadiran pancasila memegang peranan penting dalam sistem etika bangsa ini. Juga signifikan dalam meningkatkan kompetensi, kualitas, dan integritas sumber daya manusia. Adapun makna nilai setiap pancasila adalah sebagai berikut, Sila ke-1: Ke-Tuhanan Yang Maha Esa. Menurut Prayitno nilai-nilai keTuhanan sebagaimana terkandung dalam agamaagama yang dianut bangsa mengandung nilai-nilai yang mengayomi, meliputi dan menjiwai keempat sila yang lain. Segala sesuatu yang berkaitan dengan pelaksanaan dan penyelenggaraan negara, termasuk moral penyelenggara negara, politik negara, pemerintahan negara dan peraturan perundang-undangan negara, kebebasan dan hak asasi warga negara harus dijiwai nilai-nilai Ketuhanan Yang Maha Esa. Demikian pula dengan nilai-nilai etis dalam sila pertama harus mendasari dan menjiwai nilai etis keempat sila yang lain (Prayitno, 2009).

Sila pertama ini melandasi keberadaan teori etika teonom. Menurut Agoes \& Ardana teori ini mengatakan bahwa karakter moral manusia ditentukan secara hakiki oleh kesesuaian hubungannya dengan kehendak Allah. Perilaku manusia secara moral dianggap baik jika sepadan dengan kehendak Allah, dan perilaku manusia dianggap tidak baik bila tidak mengikuti aturanaturan atau perintah Allah sebagaimana telah difirmankan dalam kitab suci (Agoes \& Ardana, 2011).
Prayitno (2009) juga mengatakan bahwa sila ini setidak-tidaknya memberikan pengakuan bahwa manusia yang hidup di negeri ini merupakan warga negara yang sah dan harus diperlakukan secara adil dan beradab oleh penyelenggara negara, termasuk hak dan kebebasannya dalam berbagai bidang. Kemanusiaan yang adil dan beradab mengandung nilai bahwa suatu tindakan yang berhubungan dengan kehidupan bernegara dan bermasyarakat didasarkan atas sikap moral, kebajikan dan sikap menjunjung tinggi harkat dan martabat manusia, serta sejalan dengan norma-norma agama dan sosial yang telah berkembang dalam masyarakat sebelum munculnya negara. Ia juga mencakup perlindungan dan penghargaan terhadap budaya dan kebudayaan yang dikembangkan bangsa yang beragam etnik dan golongan. Sila kedua ini sesuai dengan teori etika hak. Hak adalah suatu tindakan atau perbuatan dianggap baik bila perbuatan atau tindakan tersebut sesuai dengan hak asasi manusia (HAM). Teori ini sebenarnya didasarkan atas asumsi bahwa manusia mempunyai martabat yang sama (Agoes \& Ardana, 2011).

Jika kita refleksikan kembali isi kelima sila dalam Pancasila, pasti kita masih mampu mengingatnya dengan sempurna. Sudah sejak jenjang sekolah dasar, sampai kita meneruskannya kembali ke anak-cucu kita, atau setidaknya mendengarnya kembali dari mulut anak-anak yang diwajibkan untuk menghafal kelima sila tersebut, membuat Pancasila melekat erat di ingatan setiap warga negara Indonesia. Terlebih nilai-nilai yang terkandung dalam pancasila secara substansial merupakan perjanjian luhur dalam mempertahankan kualitas kebaikan dalam segala bidang kehidupan, baik agama, politik, ekonomi, sosial, hukum, budaya dan lain-lain. Namun pertanyaannya sekarang adalah, masih relevan kah nilai-nilai Pancasila tersebut dengan kehidupan kita sehari-hari, terutama dalam kaitannya dengan semangat bekerja? Mari kita coba telusuri contoh-contoh penerapan manajemen sumber daya manusia yang mencerminkan manusia Pancasila dalam dunia kerja dan perusahaan yang bisa dipraktikan.

Manajemen Sumber Daya Manusia adalah suatu ilmu atau teori atau tentang bagaimana mengatur hubungan dan peran serta fungsi sumber daya yang dimiliki oleh individu secara maksimal sehingga tercapai suatu tujuan bersama ke depannya.

Pengertian manajemen menurut Marwansyah yaitu pendayagunaan sumber daya manusia di dalam organisasi yang dilakukan melalui fungsi-fungsi perencanaan sumber daya manusia, rekrutmen dan seleksi, pengembangan sumber daya manusia, perencanaan dan 
pengembangan karir, pemberian kompensasi dan kesejahteraan, keselamatan dan kesehatan kerja, serta hubungan industrial (Marwansyah, 2010).

Manajemen Sumber Daya Manusia disebut manajemen personalia yaitu perencanaan, pengorganisasian, pengarahan dan pemutusan hubungan kerja, pengembangan kompensasi, integritas, pemeliharaan dan pemutusan hubungan kerja dengan sumber daya manusia untuk mencapai sasaran perorangan, organisasi dan masyarakat (Filippo, 1994).

Manajemen Sumber Daya Manusia dapat dipahami juga sebagai manajemen tenaga kerja yaitu pendayagunaan, pembinaan, pengetahuan, pengaturan, pengembangan, unsur tenaga kerja. Baik dan buruk karyawan ataupun pegawai untuk mencapai hasil guna dan daya guna yang sebesarbesarnya sesuai organisasi.

Dari beberapa pengertian yang telah dipaparkan diatas dapat disimpulkan bahwa Manajemen Sumber Daya Manusia adalah proses perencanaan (planning), pengorganisasian (organizing), pelaksanaan (actuating) dan pengontrolan (controlling) terhadap sumber daya manusia dalam organisasi untuk mencapai tujuan secara efektif dan efisien.

Mengembangkan dialektika Pancasila di masa kini merupakan hal yang sangat strategis. Bila segenap elemen bangsa masih meyakini kebenaran nilai-nilai Pancasila maka kini tantangannya ada pada bagaimana mengkontekstualisasikn nilai-nilai tersebut dalam setiap dimensi kehidupan, termasuk di bidang ekonomi. Satu elemen signifikan dalam perekonomian dewasa ini adalah mekanisme pengelolaan manusia (baca: manajemen sumber daya manusia) perusahaan. Ekonomi yang kuat berawal dari manajemen sumber daya manusia yang tepat, ini kiranya jargon bisnis yang ideal pasca perdagangan bebas. Di tataran praktis, manajemen yang tepat selalu dilandasi dengan misi yang kuat. Pada wilayah inilah roh dan jiwa Pancasila sebagai falsafah hidup mutlak diperlukan keberadaannya. Selain sebagai faktor pembeda, menghidupkan Pancasila pada wilayah tersebut diyakini mampu menciptakan sebuah daya saing tersendiri bagi produsen lokal.

Betapa tidak, ada begitu banyak paradigma dalam manajemen modern yang ditemukan dalam refleksi nilai-nilai Pancasila. Sebut saja langkah menempatkan tujuan maksimalisasi kesejahteraan stakeholder sebagai prioritas utama. Sebagai bentuk reaksi atas sistem kapitalisme barat, prinsip orientasi kepada stakeholder berkembang di era 90-an. Sebuah masa dimana manajemen meyakini bahwa orientasi kepada stakeholder akan memberikan dampak positif pada kelangsungan hidup perusahaan jangka panjang. Sadar atau tidak, prinsip tersebut dapat dengan mudah ditemukan pada nilai-nilai Pancasila. Secara utuh, pemahaman untuk apa perusahaan di Indonesia dikembangkan mengacu pada kelima Sila dalam Pancasila. Mulai dari paradigma bahwa bisnis merupakan talenta dari Yang Maha Kuasa. Sehingga mengelola bisnis secara tepat berarti mensyukuri setiap nikmat yang diberi sekaligus bentuk pertanggungjawaban dunia akhirat.

Selanjutnya, bentuk rasa syukur tersebut direalisasikan melalui upaya menciptakan produkproduk yang mampu mengembalikan posisi manusia dalam konteks kemanusiaan. Gerakan produk hijau atau yang berwawasan lingkungan merupakan satu bukti nyata. Tak hanya itu, kesadaran bahwa kehadiran perusahaan merupakan salah satu alat pemersatu bangsa merupakan pengimplementasian sila ketiga. Baik melalui bekerja bersama-sama tanpa memandang bulu, kebanggaan menggunakan produk karya anak negeri juga merupakan pemicu semangat kebangsaan yang efektif sehingga sejak proses eksplorasi kekayaan alam hingga konsumsi, semuanya melibatkan sumbangsih anak negeri. Maka dengan prinsip keadilan dalam ekonomi, niscaya kemakmuran akan lebih mudah terwujud. Tak dapat dimungkiri bahwa dalam operasionalisasinya, manajemen modern selalu identik dengan perubahan yang terkadang memicu konflik. Dalam kondisi tersebut, sila keempat Pancasila memberikan modal kuat, yakni menyelesaikan masalah melalui musyawarah untuk mufakat. Cara pandang Pancasila dalam dimensi ini harus diakui sangat strategis. Betapa tidak, musyawarah pada hakikatnya mampu menempatkan setiap individu lengkap dengan aspirasi kepentingannya masing-masing sehingga permufakatan yang terjadi merupakan hasil dari pengendalian diri individu demi kepentingan bersama yang lebih besar.

Demikianlah dialektika tersebut akan terus berkembang seiring perubahan zaman. Kita perlu meyakini akan relevansi kesesuaian dari nilai-nilai Pancasila dalam konteks kekinian.

Manajemen Sumber Daya Manusia memiliki ruang dan lingkup yang luas, salah satu definisi sederhana yang digunakan adalah manajemen sumber daya manusia merupakan kebijakan dan praktik yang dibutuhkan oleh seseorang untuk menjalankan aspek sumber daya manusia dari posisi seorang manajer. Pada dasarnya yang menjadi kunci kegiatan manajemen sumber daya manusia adalah sebagai berikut:

1. Kinerja pegawai atau karyawan

Tujuan suatu organisasi tidak akan terwujud tanpa adanya peran dan fungsi aktif pegawai, 
secanggih apapun alat, mesin, dan teknologi yang tersedia dalam instansi atau perusahaan namun tanpa sumber daya manusia yang andal, maka keberadaan alat, mesin dan sebagainya tidak dapat berfungsi secara maksimal. Komponen paling signifikan yang pertama adalah karyawan. Karyawan merupakan orang yang bekerja pada orang lain dan menjual jasa mereka, waktu, tenaga dan pikiran untuk perusahaan dan mendapatkan kompensasi dari perusahaan tersebut.

Kinerja karyawan adalah keseluruhan hasil kerja dan pengabdian yang dicapai oleh seseorang karyawan dalam melaksanakan tugas sesuai dengan beban dan tanggung jawab yang diberikan kepadanya. Di sini terjadi sebuah ikatan atau kontrak mengenai hak dan kewajiban masingmasing. Peranan karyawan bagi sebuah perusahaan berupa peran aktif keterlibatan mereka dalam segala aktivitas melalui sebuah perencanaan, sistem, proses, dan tujuan yang ingin dicapai oleh perusahaan. Sedangkan peranan manajemen sumber daya manusia yaitu mengatur, mengelola, mendistribusikan dan menetapkan program kepegawaian yang mencakup:

a. Jumlah, kualitas dan penetapan tenaga kerja yang efektif serta efisien dan tetap sasaran sesuai dengan kebutuhan perusahaan atau instansi.

b. Menetapkan rekrutmen penarikan, seleksi dan penempatan posisi kerja karyawan.

c. Menetapkan program kesejahteraan, pengembangan, promosi dan pemberhentian.

d. Mengetahui undang-undang tentang tenaga kerja dan hak serta kewajibannya.

Secara khusus dapat dikatakan bahwa sebuah organisasi, perusahaan atau instansi harus dapat mencari dan mendapatkan calon karyawan yang memiliki kemampuan bekerja dengan menggunakan IT/teknologi informasi, dan komunikasi yang disebut pekerja pengetahuan (knowledge worker).

Menurut Drucker (2002), kontribusi manajemen yang paling penting adalah meningkatkan produktivitas kerja pengetahuan dan pekerja pengetahuan (knowledge worker). Beberapa dasawarsa ini sudah biasa dilakukan oleh sebuah departemen atau bagian sumber daya manusia merekrut karyawan-karyawan dengan kualitas pekerja pengetahuan agar sebuah organisasi atau perusahaan dan instansi dapat mencapai keunggulan kompetitif dalam jangka panjang, sekaligus memberikan keuntungan kepada para stake holder organisasi tersebut, tidak hanya pada saat ini tetapi juga bagi keberlanjutan di masa yang akan datang.

Oleh karena itu guna peningkatan kualitas kinerja karyawan yang lebih baik, maka harus ada sistem yang benar-benar strategis, focus dan terarah agar antara tujuan dan kepentingan perusahaan serta kebutuhan karyawan mampu terealisasi dengan mudah yaitu:

a. Kompensasi/Pendapatan/gaji

1) Kompensasi/Pendapatan harus (ber)(ke)adil(an) dan sesuai, imbalan dan pendapatan harus mampu meningkatkan motivasi kerja dan loyalitas karyawan kini dan masa yang akan datang.

2) Melakukan penyesuaian yakni misalnya soal waktu penggajian/ pemberian kompensasi kerja.

b. Komunikasi timbal balik

1) Menguatkan dan mempererat hubungan antar karyawan atau antar karyawan dengan pimpinan, sehingga tercipta hubungan yang sinergis, harmonis dan konstruktif.

2) Mengantisipasi terjadinya konflik ketenagakerjaan/perburuhan.

3) Melakukan kegiatan yang kaitannya dengan integrasi dan penguatan kelembagaan sehingga tercapai kerja sama yang harmonis.

c. Informasi

1) Mengetahui kepuasan dan ketidakpuasan karyawan.

2) Mengetahui problematik yang dirasakan oleh karyawan.

3) Menentukan langkah yang tepat untuk menentukan kebijakan perusahaan.

4) Mengetahui perubahan baik di internal maupun kondisi eksternal perusahaan.

5) Melakukan analisis SWOT yang komprehensif dan holistik-integratif.

\section{Produktivitas karyawan}

Produktivitas adalah keluaran (output) produk atau pun jasa persatuan masukan (input) sumber daya yang digunakan dalam suatu proses produksi. Produktivitas dapat dinyatakan dalam ukuran fisik (physical productivity) dan ukuran financial (financial productivity). Produktivitas merupakan suatu aspek yang signifikan bagi suatu 
perusahaan, karena apabila dalam perusahaan memiliki kerja yang tinggi maka akan memperoleh keuntungan dan kelangsungan hidup perusahaan akan terjamin ke depannya.

Untuk meningkatkan produktivitas kerja perlu adanya tenaga kerja yang memiliki keterampilan dan keahlian (hard skills dan soft skills) bekerja, karena apabila tenaga kerja tidak memiliki keahlian dan keterampilan akan berakibat menurunnya produktivitas dan merugikan perusahaan.

Langkah-langkah berikut ini adalah tahapan yang harus di pertimbangkan dalam suatu rencana peningkatan produktivitas yang komprehensif dan terintegrasi, yaitu:
a. Analisis situasi dan kondisi
b. Merancang program peningkatan produktivitas.
c. Menciptakan kesadaran akan produktivitas.
d. Menerapkan program.
e. Mengevaluasi program dan memberikan umpan balik (Putti, 1989).

Produktivitas yang tinggi dapat dicapai jika didukung para karyawan yang mempunyai motivasi dan lingkungan kerja dalam melaksanakan tugas dan kewajibannya. Motivasi dapat menimbulkan kemampuan bekerja serta bekerja sama, maka secara tidak langsung akan meningkatkan produktivitas. Sedangkan apabila motivasi karyawan lebih tinggi tetapi tidak didukung lingkungan kerja yang nyaman untuk bekerja maka hasil produktivitas kerja tidak baik.

\section{Semangat kerja karyawan}

Suatu organisasi atau perusahaan dalam meningkatkan produktivitas perlu adanya semangat kerja dari setiap karyawannya. Menurut Sculler dan Jakson (Sunarto, 2005) semangat kerja merupakan kondisi bagaimana seseorang pegawai melakukan pekerjaan setiap hari. Semakin tinggi semangat kerja maka akan meningkatkan produktivitas kerja pegawai. Tingkat semangat kerja pegawai dapat dilihat dari tingkat kehadiran, kegelisahan kerja, tingkat perpindahan, dan banyak tuntutan kerja pegawai. Setiap pegawai pada perusahaan pastilah akan menghadapi permasalahan-permasalahan yang akan mengakibatkan tekanan kerja yang tinggi. Hal ini yang mengkondisikan pegawai sulit memiliki semangat dalam bekerja. Sehingga di buat desain pekerjaan organisasi yang terstruktur dan jelas untuk membantu mempengaruhi secara positif kondisi kerja untuk membantu membangkitkan semangat kerja pada pegawai. Desain pekerjaan adalah spesifikasi isi metode dan hubungan berbagai pekerjaan untuk memenuhi tuntutan bisnis dan kebutuhan pribadi pemegang kebutuhan secara individu maupun tim. Apabila desain pekerjaan yang diberikan kurang jelas akan mengakibatkan pegawai kurang mengetahui tugas dan tanggung jawab yang akan mempengaruhi semangat pegawai dalam bekerja.

Sebuah Perusahaan dapat dikatakan memiliki sistem manajemen sumber daya manusia yang baik adalah jika mampu mempertimbangkan setiap sumber daya manusia yang akan berkarier dan bergabung serta mendesain berbagai program manajerial dan tutorial yang jelas dan berkelanjutan. Setiap tahunnya perusahaan tersebut mesti merekrut individu-individu terbaik dari berbagai perguruan tinggi terbaik. Perusahaan tersebut juga mempunyai program manajemen sumber daya manusia sendiri yang disebut dengan program latihan kerja atau LATKER. Program latihan kerja tersebut dibentuk untuk meminimalisasi tidak meratanya sumber daya manusia di dalam perusahaan.

Teknik manajemen sumber daya manusia bisa dibagi menjadi tiga hal, yaitu:

a. Rekrutmen, yaitu merupakan proses pengadaan sumber daya manusia dan orientasi seperti program latihan kerja.

b. Penggunaan, yaitu proses sinkronisasi antara kemampuan sumber daya manusia dengan tugas apa yang akan menjadi tanggung jawabnya.

c. Pemeliharaan, yaitu cara Perusahaan menciptakan lingkungan kerja yang nyaman sehingga karyawan juga dapat merasa puas bekerja secara optimal di dalam perusahaan.

Setelah terpilih dari proses rekrutmen, para calon tenaga kerja baru akan mengikuti dua program LATKER, yaitu:

a. On the job training, yaitu kegiatan menempatkan calon karyawan baru pada tempat kerja sesungguhnya. Pada pelatihan ini, calon tenaga kerja akan dilatih bagaimana cara kerja secara langsung dengan target tetapi didampingi oleh pembimbing. Kegiatan tersebut dilakukan selama 3 bulan yang mana peserta dapat belajar langsung tentang proses produksi, pemasaran, dan keuangan.

b. Off the job training, yaitu kegiatan ceramah kelas dan presentasi video yang menjelaskan tentang seluk beluk berkarier di dalam perusahaan. 
Studi tentang manajemen sumber daya manusia tak dapat dipisahkan dari pemahaman pandangan hidup bangsa Indonesia, yaitu Pancasila. Selain karena nilai-nilai Pancasila telah melekat dalam sanubari dan hidup masyarakat Indonesia, kajian ilmiah dari setiap sila ternyata berpotensi untuk membawa bangsa ini keluar dari problematik ekonomi dan bisnis.

Kita dapat membahas dua hal khusus yakni membahas semangat yang ditimbulkan oleh dua sila pertama dalam Pancasila, Ketuhanan yang Maha Esa, dan Kemanusiaan yang Adil dan Beradab. Meski sebagian pihak mendikotomikan secara jelas implementasi keimanan atau kepercayaan keagamaan dengan bisnis, kenyataannya di lapangan sangatlah berbeda, mulai praktik korupsi yang luar biasa hingga praktik monopoli demi kepentingan individu maupun golongan setidaknya mengingatkan kita akan semangat sila pertama Pancasila. Perwujudan nyata nilai Ketuhanan yang Maha Esa diawali dengan pemahaman bahwa setiap pribadi memiliki tanggung jawab atas setiap tutur kata maupun perilakunya, baik ketika di dunia maupun di akhirat. Karena itu, ketika seseorang melakukan aktivitas ekonomi pun tak dapat terhindar dari tanggung jawab tersebut.

Semangat itulah yang hendaknya dipahami setiap perusahaan yang beraktivitas di Indonesia. Pemahaman bahwa keberadaan perusahaan adalah tidak lain dan tidak bukan untuk turut mewujudkan kehidupan ekonomi masyarakat yang lebih baik di Indonesia maupun internasional merupakan perwujudan nyata sila pertama. Bagi sebagian pihak, bukanlah hal yang sulit untuk menjadikan pandangan tersebut sebagai sebuah panduan operasional dalam menjalankan usahanya. Kesadaran bahwa perusahaan telah mengambil keuntungan dari aktivitas eksplorasi bahkan terkesan eksploitasi alam bumi pertiwi yang merupakan anugerah Tuhan yang Maha Esa telah membawa manajemen kepada sebuah visimisi bisnis yang kuat; memandang bisnis tak hanya business as usual melainkan juga sebagai sebuah amanah dan bernilai ibadah. Oleh karena itu, saat ini tantangannya adalah bagaimana fungsi manajemen mampu menjalankan amanah tersebut. Nah, sila kedua lah yang menjadi jalan keluarnya. Pada sila kedua, perusahaan diarahkan untuk memahami dan menghargai hak asasi manusia. Oleh karena itu, orientasi pada aspek kemanusiaan dalam setiap keputusan bisnis haruslah menjadi indikator kesuksesan bisnis usaha di Tanah Air. Seperti apa produk (barang dan jasa) yang dihasilkan perusahaan mampu meningkatkan kualitas hidup konsumen dalam dimensi kemanusiaan sesuai konteks di Indonesia.
Beberapa dimensi kemanusiaan yang dikenal dari Indonesia adalah semangat gotong-royong, tolong menolong, dan memahami serta menghargai perbedaan/keberagaman sebagai sebuah sumber kekuatan atau potensi. Contoh nyata, semangat "memanusiakan manusia" ini juga harus dilakukan pada sisi internal. Melalui stakeholder, manajemen kembali diingatkan untuk memandang karyawan/tenaga kerja sebagai pihak yang harus dilayani. Sama seperti konsumen, karyawan adalah rekan perusahaan bertumbuh. Intinya, kebijakan pengembangan, peningkatan kemampuan dan kapabilitas karyawan dari level mana pun harus dibutuhkan agar kedua belah pihak sama-sama mampu mencapai kesejahteraan yang lebih baik. Meski terkesan cukup ideal, sebagian kalangan meyakini bahwa kekuatan manajemen internal perusahaan merupakan sumber pencapaian kinerja perusahaan yang sangat efektif. Realitas objektif saat ini di lapangan menunjukkan bahwa pemimpin dunia perusahaan-perusahaan di pasar global saat ini didominasi perusahaan-perusahaan yang dikenal mampu mengembangkan, mendayagunakan sekaligus memberikan kepuasan kerja yang tinggi pada segenap karyawannya.

Lewat berbagai kebijakannya, manajemen sumber daya manusia berlandaskan pancasila harus mampu memberikan ruang apresiasi bagi setiap kinerja karyawan. Mulai penghargaan akan ide dan kreativitas hingga komitmen yang telah ditunjukkan. Akhirnya, pada level tersebut, loyalitas dan komitmen karyawan yang disertai dengan rasa memiliki akan mampu memperpanjang usia operasional perusahaan secara berkelanjutan. Dan tentunya keberhasilan tersebut tidak terlepas dari upaya dalam pelaksanaan strategi pengembangan sumber daya manusia yang meliputi:

a. Mengembangkan kompetensi dalam bidang pekerjaan melalui pengadaan kursus dan pelatihan di lapangan.

b. Memacu motivasi kerja dan semangat belajar dengan mendorong karyawan untuk meningkatkan kemampuan diri serta menciptakan suasana yang kondusif.

c. Meningkatkan wawasan aspiratif dan ethical melalui pendidikan umum baik secara formal maupun informal.

d. Menyelenggarakan training bagi management trainee dengan berbagai metode seperti lokakarya, seminar, kerja lapangan, dan coaching on the job yang terpadu. 
e. Melakukan rekrutmen setiap tahun untuk mendapatkan management trainee melalui seleksi yang ketat, dilakukan secara terbuka untuk mendapatkan calon manajer yang tepat dan terbaik untuk perkembangan di masa yang akan datang.

f. Pengembangan wawasan bagi para manajer dengan cara cross posting yaitu menempatkan manajer suatu bagian ke bagi lain sehingga wawasan dan menguasai berbagai bidang pekerjaan. Terdapat pula on the job training di luar negeri, pertukaran manajer antar negara dalam jangka pendek atau penugasan expatriate di dalam negeri dalam jangka panjang. Tujuan dari strategi ini agar terjadinya proses saling tukar ide.

\section{KESIMPULAN}

Manajemen Sumber Daya Manusia adalah perencanaan pengorganisasian, pelaksanaan dan pengontrolan terhadap sumber daya manusia dalam organisasi untuk mencapai tujuan secara efektif dan efisien. Kinerja karyawan adalah hasil kerja secara kualitas dan kuantitas yang dicapai oleh seseorang karyawan dalam melaksanakan tugas sesuai dengan tanggung jawab yang diberikan kepadanya.

Produktivitas adalah keluaran (output) produk ataupun jasa persatuan masukan (input) sumber daya yang digunakan dalam suatu proses produksi. Motivasi adalah kumpulan perilaku yang memberikan landasan bagi seseorang untuk bertindak dalam suatu cara yang di arahkan kepada tujuan spesifik tertentu Tujuh faktor penting yang digunakan untuk memotivasi kinerja karyawan (motivator) yaitu: Prestasi, Pengakuan, Tantangan, Kepentingan, Tanggung jawab, Promosi, Kompensasi/Gaji dan tunjangan.

Semangat kerja merupakan kondisi bagaimana seseorang pegawai melakukan pekerjaan setiap hari. Semakin tinggi semangat kerja maka akan meningkatkan produktivitas kerja pegawai. Kepuasan kerja adalah sikap umum yang merupakan pencerminan dari beberapa sikap yang saling terikat dari seseorang terhadap pekerjaan.
Dimensi tradisi kearifan lokal (local genius) yang paling mengakar dan kita kenal di Indonesia adalah semangat gotong-royong, tolong menolong, dan memahami serta menghargai perbedaan/keberagaman sebagai sebuah sumber kekuatan atau potensi. Contoh nyata, semangat "memanusiakan manusia" ini juga harus dilakukan pada sisi internal. Akhirnya kita dapat memahami bahwa memang ada konsep manajemen sumber daya manusia modern yang dapat digali dan diterapkan dari pemahaman praktik nilai-nilai Pancasila dalam kehidupan perusahaan sehari-hari, terutama berlandaskan pada sila pertama dan kedua.

\section{UCAPAN TERIMA KASIH}

Dalam penelitian penulis mengucapkan terima kasih kepada pihak-pihak yang telah membantu terselesaikan penelitian ini terutama pada Bapak Edi Safitri dan Bapak Ahmad Asroni yang telah mencarikan buku kepustakaan terkait penelitian yang penulis teliti. Oleh karena itu, semoga segala kebaikan mereka dibalas oleh Allah swt. Aamiin.

\section{DAFTAR PUSTAKA}

Agoes, S., \& Ardana, I. C. (2011). Etika Bisnis dan Profesi: Tantangan Membangun Manusia Seutuhnya. Salemba Empat.

Drucker, P. F. (2002). Innovation and Entrepreunership Practice and Principles (Terjemah M). Harper \& Row Publiser Inc.

Filippo, E. B. (1994). Manajemen Personalia (Revisi). Erlangga.

Marwansyah. (2010). Manajemen Sumber Daya Manusia. Alfabeta.

Prayitno, H. (2009). Pancasila Sebagai Sumber Etika. http://herwanprayitno.staff.unis.ac.id

Putti, J. M. (1989). Produktivitas Kerja. Kohlers.

Sunarto. (2005). Manajemen Sumber Daya Manusia Strategik. Amus. 
Alif Lukmanul Hakim, dkk. Manajemen sumber daya manusia dalam perusahaan berdasarkan nilai Pancasila 